\title{
Obesity - New Threat to Croatian Longevity
}

\author{
Sanja Musić Milanovići, ${ }^{1,2}$ Davor Ivanković ${ }^{1}$, Ana Ivičević Uhernik² ${ }^{2}$ Kristina Fišter ${ }^{1}$, Renata Peternel ${ }^{3}$ \\ and Silvije Vuletić ${ }^{1}$ \\ ${ }^{1}$ University of Zagreb, School of Medicine, »Andrija Štampar« School of Public Health, Department of Medical Statistics, \\ Epidemiology and Medical Informatics, Zagreb, Croatia \\ ${ }^{2}$ Croatian National Institute of Public Health, Zagreb, Croatia \\ ${ }^{3}$ University of Applied Science, Velika Gorica, Croatia
}

\begin{abstract}
A B S T R A C T
The aim of this study was to examine the association of weight gain and life expectancy at birth in Croatia. Mean body mass index was based on the data from the Croatian Adult Health Survey 2003. Birth rate and mortality data needed for life expectancy calculation were supplied by the Central Bureau of Statistics. The results suggest that the increase in mean body mass index value (1.31 $\mathrm{kg} \mathrm{m}^{-2}$ for women and $1.41 \mathrm{~kg} \mathrm{~m}^{-2}$ for men) will shorten life expectancy at birth for one year. Obesity, if unchecked, might have a negative effect on life expectancy in Croatia. Despite widespread knowledge about how to reduce the severity of the problem, observed trends in obesity in Croatia continue to worsen. These trends threaten to diminish the health and life expectancy of current and future generations.
\end{abstract}

Key words: body mass index, longevity, CroHort study

\section{Introduction}

Forecasts of life expectancy are an important component of public policy that influences age-based entitlement programs such as Social Security and Medicare. Although the Croatian Administration raised its estimates of how long Croats are going to live in the 21st century, current trends in obesity in Croatia suggest that these estimates may not be accurate. From our analysis of the effect of obesity on longevity, we conclude that the steady rise in life expectancy during the past two centuries may soon come to an end.

The trend in the life expectancy of humans during the past one thousand years has been characterized by a slow and steady increase $\mathrm{e}^{1,2}$ - a pattern frequently punctuated by a volatility in death rates caused by epidemics and pandemic infectious diseases, famines, and $\mathrm{war}^{3,4}$.

Overweight and obesity have become one of the major health problems of the world today, replacing the importance of significant causes of poor health in the past, such as infectious diseases and malnutrition ${ }^{5}$. Obesity is widely accepted as an important risk factor for many chronic diseases, namely cardiovascular disease, hypertension, stroke, diabetes mellitus, and certain cancers ${ }^{6,7}$.
A modern life style, food rich in free sugars and saturated fats, and reduced physical activity have led to a concerning increase in the prevalence of overweight and obesity. According to the prediction of the World Health Organization (WHO), 300 million people in the world are likely to be obese by the year $2025^{8}$. The United States of America (USA) reported that $60.5 \%$ of adult population was overweight, $23.9 \%$ obese, and $3.0 \%$ extremely obese in 2005. Also, they encountered a substantial increase in age-adjusted obesity rates from 1995 to 2005 (15.6\% in $1995,19.8 \%$ in 2000 , and $23.7 \%$ in 2005$)^{9}$. In Croatia, the prevalence of obesity and other cardiovascular disease risk factors is also high, with substantial differences among country regions ${ }^{10}$. Obesity, defined as body mass index (BMI) $\geq 30 \mathrm{~kg} \mathrm{~m}^{-2}$ ranged from $17 \%$ to $25 \%$ for men, and from $12 \%$ to $26 \%$ for women. Two thirds of adults in Croatia today are obese or overweight. One in five adults in Croatia is obese. The largest share of obese population belongs to the $45-54$ age group; specifically $27.85 \%$ men and $32.82 \%$ women. The lowest share of obese adults come from the West region (15.54\%; 95\% CI 12.55-18.52), the highest from the North $(25.59 \%$; 95\% CI 23.37-27.81). The prevalence of obesity among adults in Croatia has 
increased. The average annual rate of increase in the prevalence of obese adults between 2003 and 2008 was $10.60 \%$ for men, $11.08 \%$ for women. These trends have affected sexes, all ages, all regions of the country and all socioeconomic strata, with the largest increases in obesity occurring in the lowest socioeconomic strata.

In addition to affecting health, obesity has been shown to have a substantial negative effect on longevity, reducing life by estimated 5 to 20 years among people who are severely obese ${ }^{11}$. The effect of body weight on mortality has been studied extensively. In a study ${ }^{12}$ of more than a million United States (US) adults, the lowest death rates were found among men with a BMI of $23.5-24.9 \mathrm{~kg} \mathrm{~m}^{-2}$ and among women with a BMI of $22.0-23.4 \mathrm{~kg} \mathrm{~m}^{-2}$. A study on life expectancy at birth in the USA revealed that life expectancy would be higher by $0.33-0.93$ years for white males and $0.30-0.81$ years for white females if obesity did not exist ${ }^{13}$. One of the hypothesized mechanisms through which obesity is reducing life expectancy is heightened oxidative stress present in obese individuals (and smokers), which increases the rate of telomere erosion per replication. Telomeres of obese women were $240 \mathrm{bp}$ shorter than those of lean women ${ }^{14}$.

The aim of this study was to assess the correlation between weight gain and life expectancy.

\section{Sample and Methods}

\section{Sample}

This survey was conducted between April and June 2003 on a sample of 10766 individuals older than 18 years from six regions in Croatia: Northern, Southern, Eastern, Western, Central and City of Zagreb. These regions were defined by the Central Bureau of Statistics in order to reflect the specifics in geographic features as well as population structure and lifestyle. Source for the selection of respondents was the 2001 Croatian Census of Population. Data were collected by public health nurses who collected anthropometric measures (height, weight, blood pressure) and interviewed respondents. Response was obtained from 9070 individuals. The overall response rate was $84.3 \%$. Each respondent was given a survey weight which corresponds to the number of persons represented by that respondent for the entire population. Survey weight calculation procedure included adjustment for multistage sample design, non-response as well as post-stratification which was done to ensure that the sum of the final weights corresponds to the population counts at the regional level ${ }^{15}$.

Birthrate and mortality data needed for life expectancy calculation were supplied by the Central Bureau of Statistics.

\section{Variables}

Self-reported body weight and height were used to calculate BMI. BMI was calculated as weight in kilograms divided by the square of height in meters. Respondents whose BMI was $30 \mathrm{~kg} \mathrm{~m}^{-2}$ or higher were classified as obese. Life tables were calculated by Chiang method ${ }^{16}$.

\section{Statistical analysis}

Correlation between mean BMI and estimated life expectancy at birth for regions was measured by Pearson's correlation coefficient ( $r$ ) and coefficient of determination $\left(\mathrm{r}^{2}\right)$ was calculated in order to estimate the proportion of the variability of life expectancy at birth that can be attributed to its linear relationship with mean BMI.

Statistical analysis was performed using Statistics Package for Social Sciences (SPSS) (version 14.01; License: Croatian National Institute of Public Health, SPSS ID: 729038). BOOTVARE_V21.SPS Program (Version 2.1; author: Statistics Canada) was used for calculating confidence intervals by using »bootstrap « method which takes into account sample design information when calculating variance estimates and measures the potential size of the sampling error ${ }^{14,17,18}$.

\section{Results}

Method of linear regression was used to analyze the impact of an increase in mean BMI value on life expectancy at birth, separately for men and women in each of the six Croatian regions.

For women, a highly significant association was found between mean BMI and life expectancy at birth for regions $(r=-0.949$ at $p=0.004)$, indicating that as the mean $\mathrm{BMI}$ increases for a region, life expectancy at birth decreases. Slope of 1,31 indicates that for every $1,31 \mathrm{~kg}$ of increase in mean BMI for women in a certain region, there is a decrease of 1 year in life expectancy at birth (Table 1). Even $90 \%\left(r^{2}=0.901\right)$ of variability in life expectancy at birth for women among different regions can be explained by BMI variability (Figure 1). For men, the findings have showed that the association between mean $\mathrm{BMI}$ and life expectancy at birth for regions was inversely related, as for a women, though not significant $(\mathrm{r}=-0.324$ at $\mathrm{p}=0.53)$. Slope of 1,41 indicates that for every $1,41 \mathrm{~kg}$ of increase in mean BMI for men in a certain

TABLE 1

CORRELATIONS OF BODY MASS INDEX (BMI) AND LIFE EXPECTANCY AT BIRTH, BY SEX AND REGIONS

\begin{tabular}{lcccc}
\hline $\begin{array}{l}\text { Regions of } \\
\text { Croatia }\end{array}$ & $\begin{array}{l}\text { Life expectancy } \\
\text { at birth (years) }\end{array}$ & BMI & $\begin{array}{l}\text { Life expectancy } \\
\text { at birth (years) }\end{array}$ & BMI \\
\cline { 2 - 5 } & Men & \multicolumn{3}{c}{ Women } \\
\hline $\begin{array}{l}\text { City of } \\
\text { Zagreb }\end{array}$ & 71.51 & 26.64 & 77.76 & 25.80 \\
Eastern & 69.54 & 26.46 & 76.76 & 26.45 \\
Southern & 72.53 & 27.07 & 78.64 & 25.37 \\
Western & 71.89 & 26.31 & 77.64 & 25.55 \\
Eastern & 69.51 & 27.02 & 76.59 & 26.61 \\
Northern & 68.61 & 27.20 & 76.57 & 26.81 \\
\hline
\end{tabular}



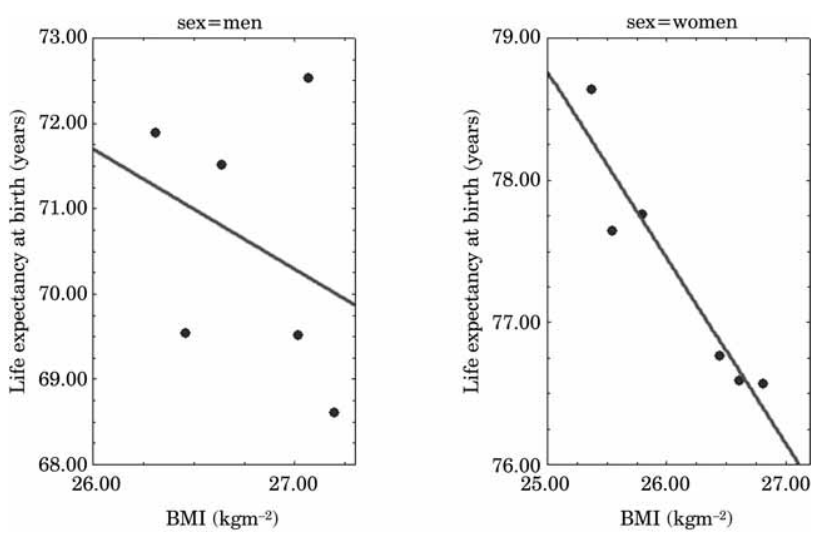

Fig. 1. Association of weight gain with life expectancy at birth, by sex

region, there is a decrease of 1 year in life expectancy at birth (Table 1$)$. Only $10 \%\left(r^{2}=0.105\right)$ of variability in life expectancy at birth for men among different regions can be explained by BMI variability (Figure 1).

\section{Discussion}

An analysis of the impact of obesity on life expectancy at the population level has shown that an increase in mean BMI value of $1,31 \mathrm{~kg} \mathrm{~m}^{-2}$ in women and $1,41 \mathrm{~kg} \mathrm{~m}^{-2}$ in men of a given region results in a decline in life expectancy at birth by one year in both sexes in that region. Obesity significantly contributes to a drop in life expectancy in women, accounting for as much as $90 \%$ of change in female longevity in Croatia. The result of the present study matches the result of the only so far published study of the effect of obesity on life expectancy at birth. It is an American study which demonstrated that a rise in BMI by $1 \mathrm{~kg} \mathrm{~m}^{-2}$ shortens life expectancy by $0.33-0.93$ in men and $0.30-0.81$ in women ${ }^{13}$. One of the presupposed mechanisms shortening longevity is augmentation of oxidative stress in obese persons, which causes damage to telomeres in replication. Telomeres of obese women are 240 bp shorter than those of lean women ${ }^{14}$. As studies of the impact of obesity on life expectancy are still exceptionally rare, the present analysis is one of the first of its kind and, thus, incomparable to the majority of similar studies.

Certain limitations of this study should be taken into account in interpretation of its results: self-reporting of height and weight might have also been influenced by response bias. It should be noted, however, that data from studies on the relation between BMI and mortality have been interpreted by some to suggest that current tables of ideal height and weight and, by extension, ideal ranges of BMI, should be adjusted to include lower ideal weights for height or BMIs before age 40, as well as higher ideal weights for height or BMIs after age $40^{19}$. Redefining ideal weights for height in this way would increase the projected negative effect of obesity on life expectancy due to a substantial increase in obesity now observed among people under age 40 .
We anticipate that as a result of the substantial rise in the prevalence of obesity and its life-shortening complications such as diabetes, life expectancy at birth and at older ages could level off or even decline within the first half of this century. This is in contrast to expectations in Croatia to raise its forecast of life expectancy and what we consider to be a simple but unrealistic extrapolation of past trends in life expectancy into the future. Advances in the medical treatment of major fatal diseases, including the complications of obesity, are likely to continue. Unfortunately, recent trends in the prevalence of cancer and in the rates of death from cardiovascular diseases in Croatia reveal only marginal gains in longevity in recent decades, and even the gains produced from the elimination of any one of today's major fatal disease ${ }^{20}$ would not exceed the negative effects of obesity that appear to be forthcoming.

A levelling off or decline in life expectancy in Croatia is not inevitable. We remain hopeful that the public health community and public policy-makers will respond to the impending dangers that obesity poses to both the quality and the length of life. However, the negative effect on health and longevity of uncontrolled obesity is substantial according to statistics on health and mortality that can be observed for the generations currently alive, as has already been shown in Okinawa, Japan ${ }^{21}$. It is important to emphasize that our conclusions about the future are based on our collective judgment, as are all forecasts, and we acknowledge that forces that influence human mortality tend to change rapidly.

Finally, our forecast has other public policy implications. We expect to see large increases in Medicare costs associated with obesity and its complications ${ }^{22}$. With rapid escalation of the prevalence of diabetes, and a decrease in mean age at the onset of diabetes, the cost of treating diabetes-related complications, such as heart disease, stroke, limb amputation, renal failure and blindness, will increase substantially. A similar escalation of health care costs due to other complications associated with obesity (e.g., cardiovascular disease, hypertension, asthma, cancer, and gastrointestinal problems) is inevitable.

Unless effective population-level interventions to reduce obesity are developed, the steady rise in life expectancy observed in the modern era may soon come to an end and the youth of today may, on average, live less healthy, and possibly even shorter, lives than their parents.

The optimism of scientists and policymakers about the future course of life expectancy should be tempered by a realistic acknowledgment that major threats to the health and longevity of younger generations today are already visible.

\section{Acknowledgements}

This article was prepared as part of the scientific project » Regionalism of cardiovascular behavioural risk factors - model of intervention « (108-1080135-0264) supported by the Ministry of Science, Education and Sports of the Republic of Croatia. 


\section{R E F E R E N C E S}

1. MACDONELL WR, Biometrika, 9 (1913) 366 — 2. FABER JF, Life tables for the United States: 1900-2050 (Social Security Administration publication no. 11-11534, Baltimore, 1982). - 3. OLSHANSKY SJ, CAR NES BA, Prospects for extended survival: a critical review of the biological evidence. In: CASELLI G, LOPEZ AD (Eds) Health and mortality among elderly populations (Oxford, England, 1996). - 4. MCNEILL WH Plagues and peoples (Garden City, New York, 1976). - 5. WORLD HEALTH ORGANIZATION, Obesity: Preventing and Managing the Global Epidemic (Report of a WHO Consultation on Obesity, Geneva, 1998) - 6. MUST A, SPADANO J, COAKLEY EH, FIELD AE, COLDITZ G, DIETZ WH, JAMA, 282 (1999) 1523. — 7. EBBELING CB, PAWLAK DB, LUDWIG DS, Lancet, 360 (2002) 473. - 8. HUBERT HB, FEINLEIB M, MCNAMARA PM, CASTELLI WP, Circulation, 67 (1983) 968. - 9. CENTERS FOR DISEASE CONTROL AND PREVENTION, State-Specific Prevalence of Obesity Among Adults - United States, 2005. Morbidity and mortality weekly report 2006; 55:985-988., accessed 09.03.2007. Available from: http://www.cdc.gov/mmwr/preview/mmwrhtml/mm5536a1.htm. 10. MUSIĆ MILANOVIĆ S, Demografic, bihevioral and socioeconomic determinants of obesity among adults in Croatia. PhD Thesis. In Croat (University of Zagreb, Zagreb, 2010). - 11. FONTAINE KR, REDDEN
DT, WANG C, WESTFALL AO, ALLISON DB, JAMA, 289 (2003) 187. 12. CALLE EE, THUN MJ, PETRELLI JM, RODRIGUEZ C, HEATH CW JR, N Engl J Med, 341 (1999) 1097. — 13. OLSHANSKY SJ, N Engl J Med, 352 (2005) 11. - 14. VALDES AM, ANDREW T, GARDNER JP, KIMURA M, OELSNER E, CHERKAS LF, AVIV A, SPECTOR TD, Lancet, 366 (2005) 662. - 15. VULETIC S, POLASEK O, KERN J, STRNAD M, BAKLAIC Z, Coll Antropol, 33 (2009) 3. - 16. NEWELL C, Methods and Models in Demography. (John Wiley \& Sons Ltd, England, 1994). 17. RUST K, RAO JNK, Stat Methods Med Res, 5 (1996) 281 - 18. YEO D, MANTEL H, LIU TP, Bootstrap variance estimation for the national population survey. In: AMERICAN STATISTICAL ASSOCIATION: Proceedings of the Survey Research Methods Section (American Statistical Association, Baltimore, 1999). — 19. ANDRES R, ELAHI D, TOBIN JD, MULLER DC, BRANT L, Ann Intern Med, 103 (1985) 1030. — 20. HRVATSKI ZAVOD ZA JAVNO ZDRAVSTVO, Hrvatski zdravstveno-statistički ljetopis za 2008. godinu. (Hrvatski zavod za javno zdravstvo, Zagreb, 2009). - 21. TODORIKI H, WILLCOX DC, WILLCOX BJ, J Am Stud, 1 (2004) 55. - 22. DAVIGLUS ML, LIU K, YAN LL, JAMA, 292 (2004) 2743.

\section{S. Musić Milanović}

University of Zagreb, School of Medicine, "Andrija Štampar « School of Public Health, Rockefellerova 4, 10000 Zagreb, Croatia

e-mail:sanja.music@hzjz.hr

\section{UTJECAJ DEBLJINE NA DUGOVJEČNOST U HRVATSKOJ: CROHORT STUDIJA}

\section{S A Ž E T A K}

Cilj ovoga rada bio je utvrditi utjecaj debljine na očekivano trajanje života (OTŽ) pri rođenju. Presječno istraživanje (Hrvatska zdravstvena anketa 2003) na reprezentativnom slučajnom uzorku od 9070 odraslih osoba bio je izvor podataka za izračun srednje vrijednosti indeksa tjelesne mase (ITM) i udjela osoba s debljinom. Izvor natalitetnih i mortalitetnih podataka potrebnih za izračun OTŽ-a je Državni zavod za statistiku. Rezultati sugeriraju da ce porast srednje vrijednosti ITM-a od 1,31 kg m${ }^{-2} \mathrm{u}$ žena, odnosno $1,41 \mathrm{~kg} \mathrm{~m}^{-2} \mathrm{u}$ muškaraca skratiti OTŽ pri rođenju za jednu godinu. O važnosti ovog negativnog utjecaja debljine na OTŽ u hrvatskoj populaciji govori i činjenica da bi to bio prvi negativni pomak u OTŽ-u od kada državna administracija vodi evidenciju o zdravstvenim pokazateljima. 